\title{
A comparative study on optimization of machining parameters by turning aerospace materials according to Taguchi method
}

\author{
Abdullah Altin* \\ Van Vocational School of Higher Education, Yuzuncu Yil University, 65100 Van, Turkey
}

Received 4 July 2016 / Accepted 21 November 2016

\begin{abstract}
The effects of cutting tool coating material and cutting speed on cutting forces and surface roughness were investigated by Taguchi experimental design. Main cutting force, $F_{\mathrm{z}}$ is considered as a criterion. The effects of machining parameters were investigated using Taguchi $\mathrm{L}_{18}$ orthogonal array. Optimal cutting conditions were determined using the signal-to-noise $(\mathrm{S} / \mathrm{N})$ ratio which is calculated for average surface roughness and cutting force according to the "the smaller is better" approach. Using results of analysis of variance (ANOVA) and signal-to-noise $(\mathrm{S} / \mathrm{N})$ ratio, effects of parameters on both average surface roughness and cutting forces were statistically investigated. It was observed that feed rate and cutting speed had higher effect on cutting force in Hastelloy X, while the feed rate and cutting tool had higher effect on cutting force in Inconel 625. According to average surface roughness the cutting tool and feed rate had higher effect in Hastelloy X and Inconel 625.
\end{abstract}

Key words: Machinability, Taguchi method, Hastelloy X, Inconel 625, Surface roughness, Cutting force.

\section{Introduction}

Advanced materials, such as nickel-base and titanium alloys as well as composites are generally used at $650{ }^{\circ} \mathrm{C}$ or higher temperatures at which high stresses occur and surface integrate required. These materials are widely used in industrial gas turbines, space vehicles, rocket engines, nuclear reactors, submarines, stream production plants petrochemical devices, hot tools and glass industries [1]. Inconel 625 has been used in aqueous corrosive environments due to its excellent overall corrosion resistance [2]. Inconel 625 (Alloy 625) is a nickel-based super alloy strengthened mainly by the solidsolution hardening of the refractory metals, niobium and molybdenum, in a nickel-chromium matrix. Alloy 625 was originally developed as a solid-solution strengthened material. It was determined that the alloy is hardenable [3-6]. Inconel 625 exhibits precipitation hardening mainly due to the precipitation of fine metastable phase $(\mathrm{Ni} 3 \mathrm{Nb})$ after annealing over a long period in the temperature range $550-850{ }^{\circ} \mathrm{C}[4,5]$. Moreover, various forms of carbides (MC, M6C and $\mathrm{M} 23 \mathrm{C} 6$ ) can also precipitate depending upon the time and temperature of aging. Alloy 625 has extensive use in many industries for diverse applications over a wide temperature range from cryogenic conditions to ultra hot environments over $1000^{\circ} \mathrm{C}$ [6-9]. Hastelloy $\mathrm{X}$ and Inconel 625 is a nickel

*e-mail: aaltin@yyu.edu.tr chromium-iron molybdenum alloy is developed for high temperature applications and it is derived from the strengthening particles, $\mathrm{Ni} 2$ (Mo, Cr), which formed after the two-step age-hardening heat treatment process. With face-centered cubic (FCC), Ni-Cr-Mo-W alloys, named as Hastelloy used for marine engineering, chemical and hydrocarbon processing equipment, valves, pumps, sensors and heat exchangers. Nickel-based super alloys have heat resistance, excellent mechanical properties, corrosion resistance and ability to operate in high temperature, attracting in nuclear industries $[10,11]$. Nickel-based alloys and super alloys are very difficult to process [12-15]. A nickel-based super alloy has generally chemical content $38-76 \%$ nickel (Ni), more than $27 \%$ chromium (Cr) and 20\% cobalt (Co) [16]. Such materials having high corrosion resistance and high strength at high temperatures are used $[12,13,17-21]$. The commercially available nickel-based super alloys are: Inconel (587, 597, $600,601,617,625,706,718, \mathrm{X} 750,901)$, Nimonic (75, $80 \mathrm{~A}, 90,105,115,263$, 942, PA 11, PA 16, PO 33, C-263), Rene (41,95), Udimet (400, 500, 520, 630, 700, 710, 720), Pyrometer 860, Astrology, M-252, Waspaloy, Unitemp AF2 IDA6, Cabot 214 and Haynes 230 [16, 22]. These alloys have excellent mechanical properties, workability and corrosion resistance in aviation and extensively in the chemical industry heaters, condensers, evaporator tubes, pipes mirrors. However, low thermal conductivity and high cutting strength is still considered as challenging $[16,23]$. 
Table 1. The chemical composition of specimens.

\begin{tabular}{cccccccccccc}
\hline Malzeme Ad1 & $\mathrm{Ni}$ & $\mathrm{Cr}$ & $\mathrm{Fe}$ & $\mathrm{Si}$ & $\mathrm{Mn}$ & $\mathrm{Mo}$ & $\mathrm{Co}$ & $\mathrm{Nb}+\mathrm{Ta}$ & $\mathrm{Al}$ & $\mathrm{P}$ & $\mathrm{Ti}$ \\
\hline Inconel 625 & 58 & 22 & 4.73 & 0.1 & 0.11 & 9.1 & 0.08 & 5.32 & 0.2 & 0.01 & 0.3 \\
Malzeme Ad1 & $\mathrm{Ni}$ & $\mathrm{Cr}$ & $\mathrm{Fe}$ & $\mathrm{Si}$ & $\mathrm{Mn}$ & $\mathrm{W}$ & $\mathrm{C}$ & $\mathrm{B}$ & $\mathrm{Mo}$ & $\mathrm{Co}$ & $\mathrm{Al}$ \\
Hastelloy X & 50 & 21 & 2 & 0.08 & 0.8 & 1 & 0.01 & 0.01 & 17 & 1 & 0.5 \\
\hline
\end{tabular}

Table 2. Mechanical properties of specimens.

\begin{tabular}{cccccc}
\hline Material & Thermal conductivity $(\mathrm{W} / \mathrm{mK})$ & Hardness $(\mathrm{RB})$ & Yield strength (MPa) & Breaking extension (5do) & Tensile strength (MPa) \\
\hline Inconel 625 & 9.8 & 97 & 758 & $60-30$ & 885 \\
Hastelloy X & 11.4 & 388 & 1170 & 23.3 & 1370 \\
\hline
\end{tabular}

\section{Materials and method}

\subsection{Experiment specimens}

Specimens of Hastelloy X and Inconel 625 which has an industrial usage, are prepared as the dimension of diameter $\varnothing 25 \times 40 \mathrm{~mm}$ then used for the experiments. The chemical composition and mechanical properties of specimens are given in Tables 1 and 2. These materials are hard to machine which make them suitable for high temperature applications.

\subsection{Machine tool and measuring instrument of cutting forces}

In the experimental study machining tests are carried out on JOHNFORD T35 industrial type CNC lathe maximum power of which is $10 \mathrm{~kW}$ and has revolution number between 50 and $3500 \mathrm{rev} / \mathrm{min}$ (Figure 1). During dry cutting process, Kistler brand 9257 B-type three-component piezoelectric dynamometer under tool holder with the appropriate load amplifier is used for measuring three orthogonal cutting forces $\left(F_{\mathrm{x}}, F_{\mathrm{y}}, F_{\mathrm{z}}\right)$. This allows direct and continuous recording and simultaneous graphical visualization of the three cutting forces (Figures 2 and 3).

\subsection{Cutting parameters, cutting tool and tool holder}

The cutting speeds 65,80 , and $100 \mathrm{~mm} / \mathrm{rev}$ were chosen by taking into consideration ISO 3685 standard as recommended by manufacturing companies. The depth of cut $1,5 \mathrm{~mm}$ feed rate $0.10-0.15 \mathrm{~mm} / \mathrm{rev}$. During cutting process, the machining tests were conducted with three different cemented carbide tools namely Physical Vapor Deposition (PVD) coated with TiN/TiCN/TiN; Chemical Vapor Deposition (CVD) coated with TIN+AL2O3-TICN+TIN; and WC/CO. The test specimens were chosen $\varnothing 25 \times 40 \mathrm{~mm}$ Properties of cutting tools and level of independent variables are given in Tables 3 and 4. Surtrasonic 3-P measuring equipment is used for the measurement of surface roughness. Measurement processes are carried out with three replications. For surface roughness on work-piece during machining, cut-off and sampling length are considered as 0.8 and $2.5 \mathrm{~mm}$, respectively. Ambient temperature is $20 \pm 1{ }^{\circ} \mathrm{C}$. The following details tool geometry
CNMG inserts when mounted on the tool holder: (a) $\mathrm{CNMG}$ shape; (b) axial rake angle: $6^{\circ}$; (c) end relief angle: $5^{\circ}$; and (d) sharp cutting edge. The insert type CNMG 120404 with $75^{\circ}$ approaching is mounted on PCLNR $2525 \mathrm{M} 12$ type tool holder. The levels for the determination of parameters estimated and actual test results $\mathrm{S} / \mathrm{N}$ ratio and cutting values are given in Table 5. ANOVA results for the main cutting force $\left(F_{\mathrm{z}}\right)$ and surface roughness $\mathrm{S} / \mathrm{N}$ ratio in Inconel 625 and Hastelloy $X$ are given in Tables 6-9 (Figures 4 and 5).

\section{Results and discussion}

\subsection{The change of main cutting force depending on cutting speed and coating material of cutting tool}

Parameter in the determination of the maximum cutting force values for each level of the small $\mathrm{S} / \mathrm{N}$ ratio determined and created new verification experiment was conducted according to the test combination. Tolerances specified for the product and quality in the design stage towards achieving the goal around the nominal value of each selected parameter to determine tolerance values. Product losses in the case where a different result from the target value by determining deviations calculated. Taguchi loss function, the expected target value and the deviation between the experimental values and the signal/noise $(\mathrm{S} / \mathrm{N})$ ratio is calculated by converting [24-26]. S/N ratio in calculating three different characteristics which are frequently used; nominal (face) value the better, smaller is better and bigger is better. In this study, the low surface roughness value, best performance will refer to the literature processed surfaces the lowest surface roughness values for the smaller the better $\mathrm{S} / \mathrm{N}$ characteristic Due to the use in the analysis of at least the surface roughness and cutting forces for the smaller the better $\mathrm{S} / \mathrm{N}$ characteristic is used. However, in experiments bigger the better $\mathrm{S} / \mathrm{N}$ characteristic may be used $[26,27]$.

The aim here is $\mathrm{S} / \mathrm{N}$ ratio is to maximize. Thus assessment for each parameter the average $\mathrm{S} / \mathrm{N}$ ratio and the largest $\mathrm{S} / \mathrm{N}$ ratio with a level, is used to determine the best results. In this study, the low surface roughness and low cutting force value represents the best performance. Parameters for each level of the average $\mathrm{S} / \mathrm{N}$ ratio by utilizing a graphical representation 


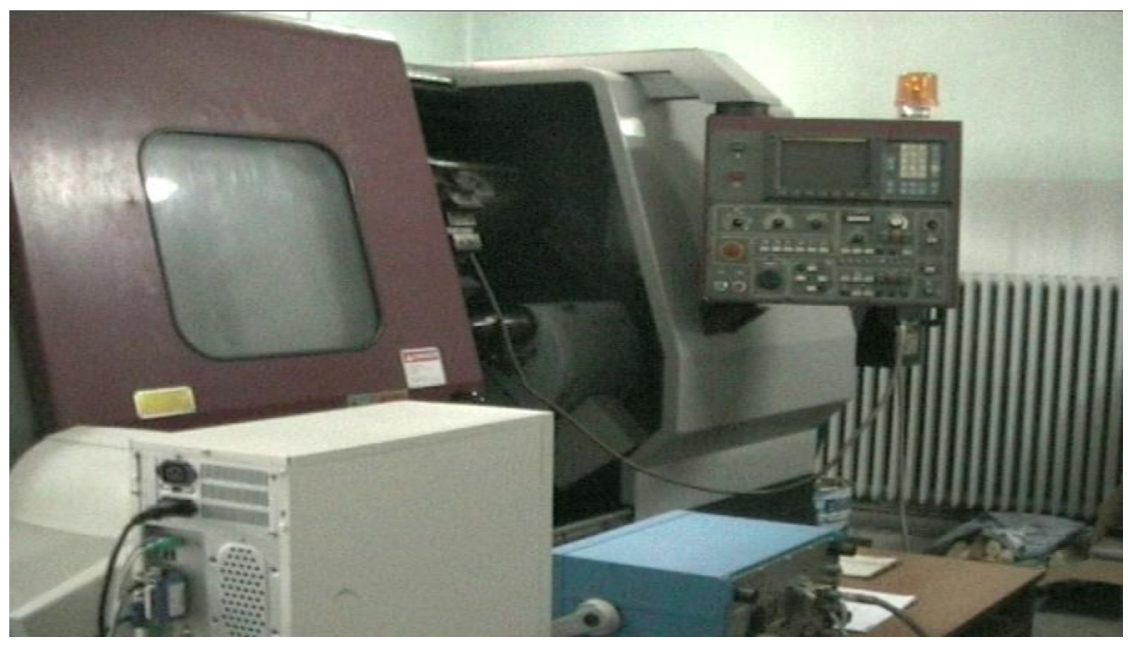

Figure 1. Cutting force measuring system used in the dynamometer, CNC JOHNFORD T35 lathe and computer unit.
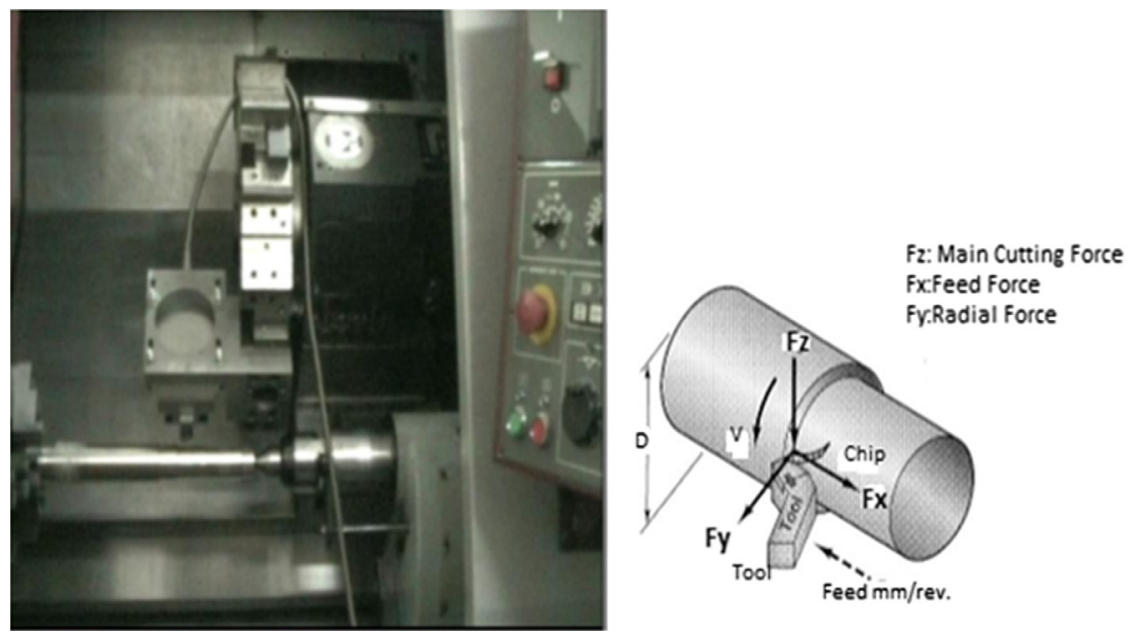

Figure 2. Kistler 9257B (1997) dynamometer (10 KW), cutting force measuring unit with JOHNFORD T35 CNC lathe.

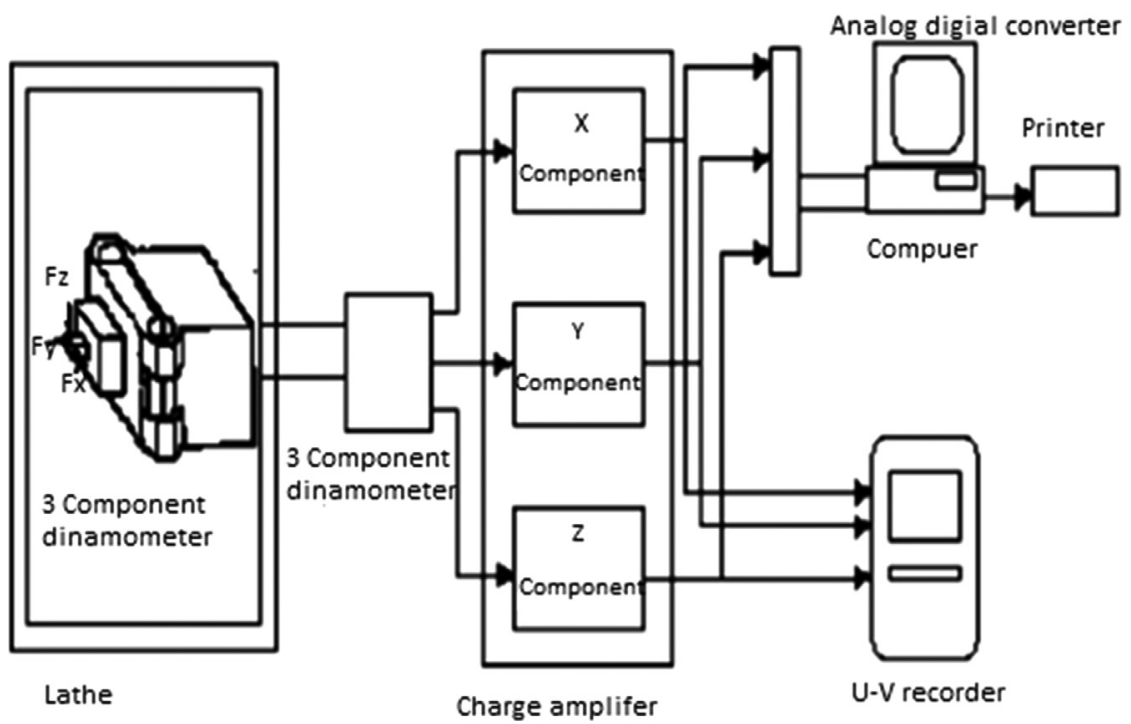

Figure 3. Measurement of cutting forces and schematically figure of dynamometer unit. 
Table 3. Properties of cutting tools.

\begin{tabular}{|c|c|c|c|c|}
\hline Coating material (top layer) & Coating method and layers & ISO grade of material (grade) & Geometric form & Manufacturer and code \\
\hline $\mathrm{TiN}$ & CVI & $\mathrm{P} 25$ & CNMG120412R & Ker \\
\hline TiN & PVD (TiN, TiCN, TiN, Wc) & P25-P40, M20-M30 & CNMG120412FN & Kennametal KT315 \\
\hline WC-CO & Uncoated & $\mathrm{P} 25-\mathrm{P} 40, \mathrm{M} 20-\mathrm{M} 30$ & CNMG120412MS & Kennametal K313 \\
\hline
\end{tabular}

Table 4. Level of independent variables.

\begin{tabular}{lccrc}
\hline \multicolumn{1}{c}{ Variables } & \multicolumn{3}{c}{ Level of variables } \\
\cline { 2 - 4 } & Lower & Low & Medium & High \\
\hline Cutting force, $v(\mathrm{~m} / \mathrm{min})$ & 50 & 65 & 80 & 100 \\
Feed rate, $f(\mathrm{~mm} / \mathrm{rev})$ & $0.1-0.15$ & $0.1-0.15$ & $0.1-0.15$ & $0.1-0.15$ \\
Depth of cut $(\mathrm{mm})$ & 1.5 & 1.5 & 1.5 & 1.5 \\
\hline
\end{tabular}

Table 5. Average surface roughness and the data obtained from actual experiments cutting force and the $\mathrm{S} / \mathrm{N}$ ratio in Hastelloy $\mathrm{X}$ and Inconel 625 .

\begin{tabular}{|c|c|c|c|c|c|c|c|c|c|c|c|c|c|}
\hline \multicolumn{8}{|c|}{ Hastelloy X } & \multicolumn{6}{|c|}{ Inconel 625} \\
\hline $\begin{array}{c}\text { Feed rate } \\
\mathrm{mm} / \mathrm{rev}\end{array}$ & $\begin{array}{c}\text { Cutting } \\
\text { force } \\
\mathrm{m} / \mathrm{min}\end{array}$ & $\begin{array}{c}\text { Cutting } \\
\text { tool }\end{array}$ & $R_{\mathrm{a}}(\mu \mathrm{m})$ & $F_{\mathrm{z}}(\mathrm{N})$ & $\begin{array}{c}\mathrm{S} / \mathrm{N} \\
\text { rate } \\
\text { For } \mathrm{Ra}\end{array}$ & $\begin{array}{c}\mathrm{S} / \mathrm{N} \\
\text { rate } \\
\text { for } F_{\mathrm{z}} \\
\end{array}$ & $\begin{array}{c}\text { Feed } \\
\text { rate } \\
\mathrm{mm} / \mathrm{rev}\end{array}$ & $\begin{array}{l}\text { Cutting } \\
\text { force } \\
\mathrm{m} / \mathrm{min}\end{array}$ & $\begin{array}{c}\text { Cutting } \\
\text { tool }\end{array}$ & $R_{\mathrm{a}}(\mu \mathrm{m})$ & $F_{\mathrm{z}}(\mathrm{N})$ & $\begin{array}{c}\mathrm{S} / \mathrm{N} \\
\text { rate } \\
\text { for } R_{\mathrm{a}} \\
\end{array}$ & $\begin{array}{l}\mathrm{S} / \mathrm{N} \text { rate } \\
\text { for } F_{\mathrm{z}}\end{array}$ \\
\hline 0.10 & 65 & K313 & 1.70 & 691 & -4.6090 & -56.7896 & 0.10 & 65 & K313 & 1.452 & 695 & -3.2393 & -56.8397 \\
\hline 0.10 & 65 & KT315 & 1.605 & 622 & -4.1095 & -55.8758 & 0.10 & 65 & KT315 & 3.179 & 560 & -10.0458 & -54.9638 \\
\hline 0.10 & 65 & КС9240 & 1.455 & 715 & -3.2573 & -57.0861 & 0.10 & 65 & КС9240 & 0.725 & 505 & 2.7932 & -54.0658 \\
\hline 0.10 & 80 & K313 & 1.599 & 655 & -4.0770 & -56.3248 & 0.10 & 80 & K313 & 1.691 & 705 & -4.5629 & -56.9638 \\
\hline 0.10 & 80 & KT315 & 1.410 & 601 & -2.9844 & -55.5775 & 0.10 & 80 & KT315 & 1.235 & 550 & -1.8333 & -54.8073 \\
\hline 0.10 & 80 & КС9240 & 1.368 & 694 & -2.7217 & -56.8272 & 0.10 & 80 & КС9240 & 0.576 & 508 & 4.7916 & -54.1173 \\
\hline 0.10 & 100 & $\mathrm{~K} 313$ & 1.717 & 658 & -4.6954 & -56.3645 & 0.10 & 100 & K313 & 1.001 & 695 & -0.0087 & -56.8397 \\
\hline 0.10 & 100 & KT315 & 1.667 & 598 & -4.4387 & -55.5340 & 0.10 & 100 & KT315 & 1.027 & 568 & -0.2314 & -55.0870 \\
\hline 0.10 & 100 & КС9240 & 0.755 & 538 & -2.4411 & -54.6156 & 0.10 & 100 & КC9240 & 0.755 & 483 & 2.4411 & -53.6789 \\
\hline 0.15 & 65 & K313 & 3.649 & 919 & -11.243 & -59.2663 & 0.15 & 65 & K313 & 0.958 & 875 & 0.3727 & -58.8402 \\
\hline 0.15 & 65 & KT315 & 2.669 & 863 & -8.5269 & -58.7202 & 0.15 & 65 & KT315 & 4.785 & 785 & -13.5976 & -57.8974 \\
\hline 0.15 & 65 & КС9240 & 1.492 & 966 & -3.4754 & -59.6995 & 0.15 & 65 & КС9240 & 1.580 & 691 & -3.9731 & -56.7896 \\
\hline 0.15 & 80 & K313 & 3.462 & 901 & -10.786 & -59.0945 & 0.15 & 80 & K313 & 1.307 & 876 & -62.3255 & -58.8501 \\
\hline 0.15 & 80 & KT315 & 1.880 & 855 & -5.4832 & -58.6393 & 0.15 & 80 & KT315 & 1.533 & 707 & -3.7108 & -56.9884 \\
\hline 0.15 & 80 & КC9240 & 1.405 & 696 & -2.9535 & -56.8522 & 0.15 & 80 & КC9240 & 1.476 & 555 & -3.3817 & -54.8859 \\
\hline 0.15 & 100 & K313 & 3.137 & 854 & -9.9303 & -58.6292 & 0.15 & 100 & K313 & 0.812 & 887 & -58.1911 & -58.9585 \\
\hline 0.15 & 100 & KT315 & 3.132 & 830 & -9.9164 & -58.3816 & 0.15 & 100 & KT315 & 0.950 & 724 & 0.4455 & -57.1948 \\
\hline 0.15 & 100 & КС9240 & 1.085 & 697 & -0.7086 & -56.8647 & 0.15 & 100 & КС9240 & 1.380 & 1.511 & -2.7976 & -63.5853 \\
\hline
\end{tabular}

Table 6. ANOVA results for the main cutting force $\left(F_{\mathrm{z}}\right) \mathrm{S} / \mathrm{N}$ ratio in Inconel 625.

\begin{tabular}{|c|c|c|c|c|c|}
\hline Source & Degrees of freedom (DoF) & Sequential sum of squares (SS) & Mean sum of squares (MS) & $F$-test & $P$-coefficient $(\%)$ \\
\hline Feed rate & 1 & 39.388 & 39.388 & 11.51 & 0.398 \\
\hline Cutting speed & 2 & 6.631 & 3.316 & 0.97 & 0.067 \\
\hline Cutting tool & 2 & 11.702 & 5.851 & 1.71 & 0.118 \\
\hline Total & 17 & 98.784 & & & \\
\hline
\end{tabular}

of an optimal level for each parameter is determined. Accordingly, the parameters determined for each level of the $\mathrm{S} / \mathrm{N}$ ratio is calculated using the estimated value. Estimated $\mathrm{S} / \mathrm{N}$ ratio and output (surface roughness or cutting) value is used in calculating the formulas 4 . The final step of the
Taguchi experimental design process includes confirmation experiments [27, 28]. Or this aim, the results of the experiments were compared with the predicted values with the Taguchi method and the error rates were obtained. $\mathrm{S} / \mathrm{N}$ ratios $\eta_{\text {predict }}$ were predicted using the following model [27-30]. 
Table 7. ANOVA results for the surface roughness $\left(R_{\mathrm{a}}\right) \mathrm{S} / \mathrm{N}$ ratio in Inconel 625 .

\begin{tabular}{|c|c|c|c|c|c|}
\hline Source & $\begin{array}{c}\text { Degrees } \\
\text { of freedom (DoF) }\end{array}$ & Sequential sum of squares (SS) & Mean sum of squares (MS) & $F$-test & $P$-coefficient $(\%)$ \\
\hline Feed rate & 1 & 1046.7 & 1046.74 & 3.49 & 0.165 \\
\hline Cutting speed & 2 & 165.4 & 82.72 & 0.28 & 0.026 \\
\hline Residual error & 12 & 3596.3 & 299.69 & & 0.570 \\
\hline Total & 17 & 6306.7 & & & \\
\hline
\end{tabular}

Table 8. ANOVA results for the cutting force $\left(F_{z}\right)$ in Hastelloy X.

\begin{tabular}{lccccc}
\hline \multicolumn{1}{c}{ Source } & $\begin{array}{c}\text { Degrees of freedom } \\
(\mathrm{DoF})\end{array}$ & $\begin{array}{c}\text { Sequential sum of squares } \\
(\mathrm{SS})\end{array}$ & $\begin{array}{c}\text { Mean sum of squares } \\
(\mathrm{MS})\end{array}$ & $\begin{array}{c}F \text {-test } \\
P(p<0.05)\end{array}$ & $\begin{array}{c}P \text {-coefficient } \\
(\%)\end{array}$ \\
\hline Feed rate & 1 & 18.1805 & 18.1805 & 57.75 & 0.002 \\
Cutting speed & 2 & 3.0700 & 1.5350 & 4.88 & 0.085 \\
Cutting tool & 2 & 1.3213 & 0.6607 & 2.1 & 0.238 \\
Residual error & 12 & 12.592 & 3.148 & 4.99 \\
Total & 17 & 27.5517 & & 4.57 \\
\hline
\end{tabular}

Table 9. ANOVA results for surface roughness $\left(R_{\mathrm{a}}\right)$ in Hastelloy X.

\begin{tabular}{lccccc}
\hline \multicolumn{1}{c}{ Source } & $\begin{array}{c}\text { Degrees of freedom } \\
(\mathrm{DoF})\end{array}$ & $\begin{array}{c}\text { Sequential sum of squares } \\
(\mathrm{SS})\end{array}$ & $\begin{array}{c}\text { Mean sum of squares } \\
(\mathrm{MS})\end{array}$ & $\begin{array}{c}F \text {-test } \\
P(p<0.05)\end{array}$ & $\begin{array}{c}P \text {-coefficient } \\
(\%)\end{array}$ \\
\hline Feed rate & 1 & 4.1424 & 4.1424 & 56.56 & 0.002 \\
Cutting speed & 2 & 0.18817 & 0.09408 & 1.28 & 0.371 \\
Cutting tool & 2 & 5.04646 & 2.52323 & 34.45 & 0.003 \\
Residual error & 12 & 0.29294 & 0.07323 & 4.51 \\
Total & 17 & 12.4974 & & 2.34 \\
\hline
\end{tabular}

$$
\eta_{\text {predict }}=\eta_{m}+\sum_{i=1}^{k n}\left(\eta_{i}-\eta_{m}\right)
$$

Here,

$\eta$ : The estimated $\mathrm{S} / \mathrm{N}$ ratio.

$\eta_{m}$ : Total average $\mathrm{S} / \mathrm{N}$ ratio.

$\eta_{i}$ : Parameter $i$ at the level of the $\mathrm{S} / \mathrm{N}$ ratio.

Here $\eta_{\text {predict }}$ is the main cutting force or $F \mathrm{z}$ with regard to the $\mathrm{S} / \mathrm{N}$ ratio.

Moreover, the optimum turning parameters were obtained for the performance characteristics using the Taguchi analysis. Where $\eta_{m}$ is the total mean of the $\mathrm{S} / \mathrm{N}$ ratios, $\eta_{i}$ is the mean $\mathrm{S} / \mathrm{N}$ ratio at the optimum level and $k$ is the number of the main design parameters that significantly affect the performance characteristics. After predicting the $\mathrm{S} / \mathrm{N}$ ratios other than experiments, the main cutting force or $F_{\mathrm{z}}$ were calculated using the following equation. The final step of the Taguchi experimental design process includes confirmation experiments $[28,29]$. For this aim, the results of the experiments were compared with the predicted values with the Taguchi method and the error rates were obtained. $\mathrm{S} / \mathrm{N}$ ratios were predicted using the following model [30]. In this research "smallest is better" was used since the minimum of the cutting force and surface roughness was intended. In the experiment, the $\mathrm{S} / \mathrm{N}$ ratio can be calculated using the following equation:

$$
\eta_{i}=-10 \log 10 \frac{1}{n} \sum_{1}^{n} Y i^{2}
$$

$\eta$ is the number of replications and $Y i$ is the measured characteristic.

$$
\text { Predict }=10^{\frac{-\mathrm{S} / \mathrm{N}}{20}}
$$

Taguchi method, used to analyze and evaluate the numerical results for the orthogonal experimental design, the $\mathrm{S} / \mathrm{N}$ ratio and ANOVA combining three tools such as the solution reaches [30-33].

\subsection{Results of Taguchi analysis}

Experiments conducted with two different cutting tool wear value obtained as a result of the L18 experimental design based on a total of 36 experiments were made orthogonal. L18 orthogonal design, in two levels, corresponding to 8 columns and 18 rows of cylindrical turning experiments (17 degrees of freedom) was formed. Cutting force and the surface roughness is small, as quality characteristics " $(\mathrm{S} / \mathrm{N}) \mathrm{SB}$, the smaller-better" is selected $[32,33]$. The average surface roughness, the main cutting force data obtained in experiments and $\mathrm{S} / \mathrm{N}$ ratios is given in Table 5 . According to the data in Table 5, the lowest main cutting force at $100 \mathrm{~m} / \mathrm{min}$ was found in Hastelloy $\mathrm{X}$ with $\mathrm{KC}$ 9240 insert as $538 \mathrm{~N}$ and in Inconel 625 as $483 \mathrm{~N}$. In Table 5 the lowest average surface roughness was found with $\mathrm{KC}$ 9240 at $100 \mathrm{~m} / \mathrm{min}$ in Hastelloy $\mathrm{X}$ as $0.755 \mu \mathrm{m}$ and in Inconel 625 as $0.725 \mu \mathrm{m}$ at $65 \mathrm{~m} / \mathrm{min}$. Determining the 
According to $F z(N)$

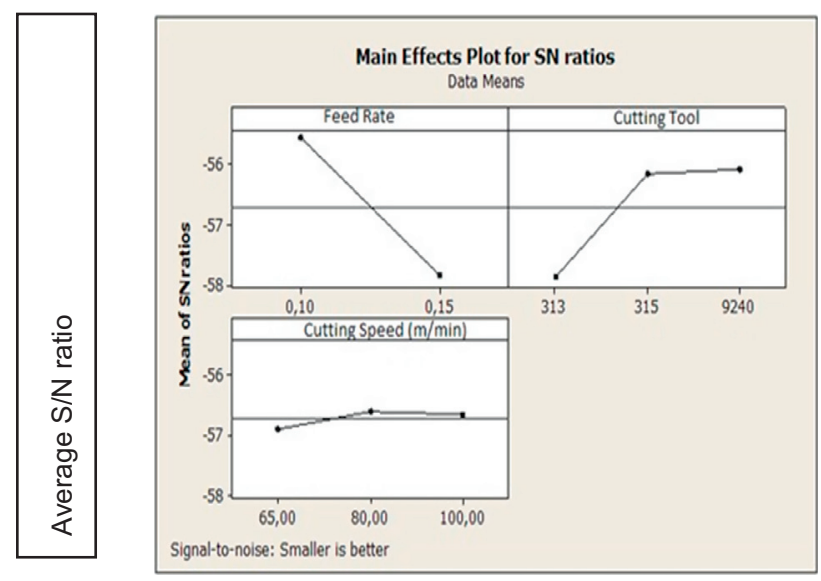

According to $R a(\mu \mathrm{m})$

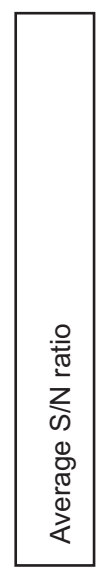

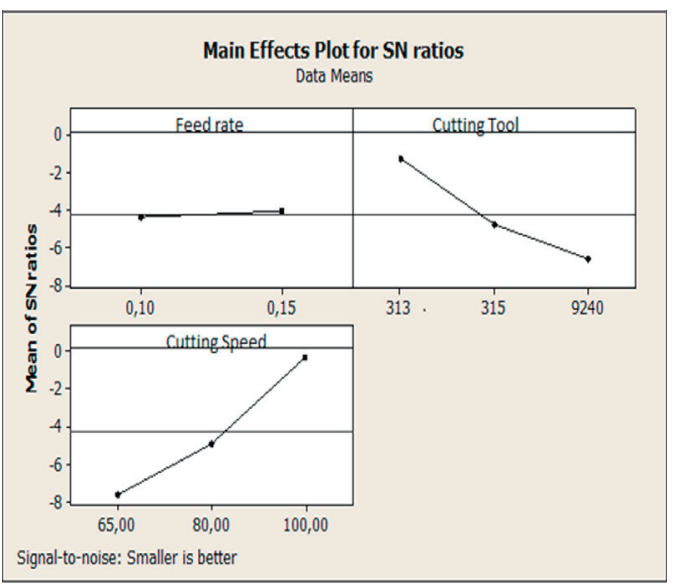

Figure 4. According to the level of machining parameters in Inconel 625 , cutting force $\left(F_{\mathrm{z}}\right)$, surface roughness Ra( $\left.\mu \mathrm{m}\right)$ the signal-to-noise $(\mathrm{S} / \mathrm{N})$ ratio).

\section{According to $F z(N)$}

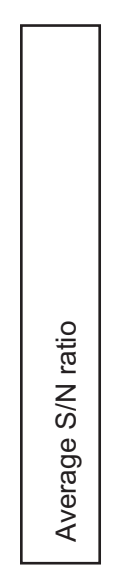

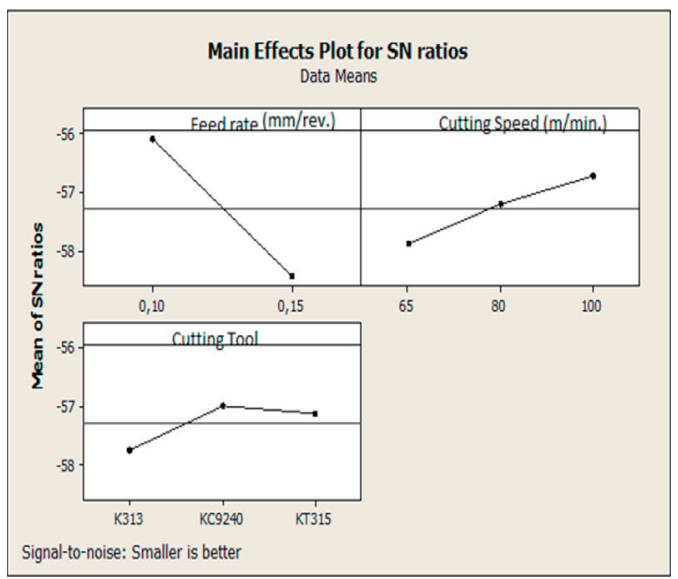

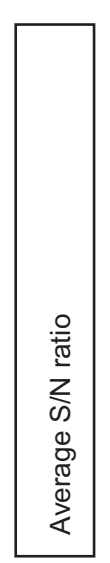

\section{According to $R a(\mu \mathrm{m})$}

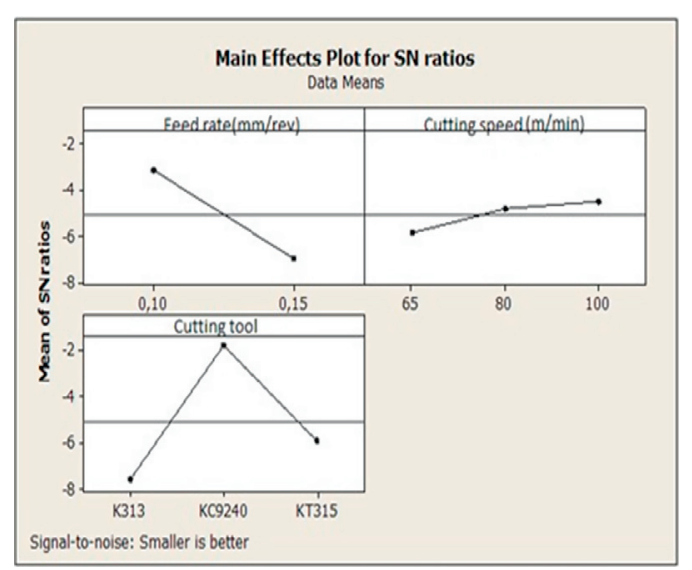

Figure 5. According to the level of machining parameters in Hastelloy $\mathrm{X}$, cutting force $\left(F_{\mathrm{z}}\right)$, surface roughness Ra( $\left.\mu \mathrm{m}\right)$ the signal-to-noise $(\mathrm{S} / \mathrm{N})$ ratio).

Table 10. Cutting force $\left(F_{\mathrm{z}}\right) \mathrm{SN}$ rates and verification test for the optimum results in Inconel 625.

\begin{tabular}{|c|c|c|c|}
\hline \multirow[t]{2}{*}{ Optimization of Taguchi } & \multicolumn{3}{|c|}{ Optimal cutting parameters } \\
\hline & & Prediction & Experimental \\
\hline Level & \multicolumn{2}{|r|}{$\mathrm{A} 1 \mathrm{~B} 2 \mathrm{C} 2$} & $\mathrm{~A} 1 \mathrm{~B} 2 \mathrm{C} 2$ \\
\hline Parameters & 0.10 & $80 \quad$ KT315 & $0.10 \quad 80 \quad$ KT315 \\
\hline Cutting force $(\mathrm{N})$ & \multicolumn{2}{|c|}{453.5} & 550 \\
\hline$\underline{\mathrm{S} / \mathrm{N} \text { ratio }}$ & \multicolumn{2}{|r|}{-54.0374} & -57.8072 \\
\hline
\end{tabular}

minimum mean surface roughness values of the parameters for each level of the large $\mathrm{S} / \mathrm{N}$ ratio determined and created new verification experiment was conducted according to the test combination. The levels for the determination of parameters estimated and actual test result $\mathrm{S} / \mathrm{N}$ ratio and the average surface roughness values are provided in Table 5.
Table 11. Average surface roughness and verification test for the optimum results in Inconel 625.

\begin{tabular}{|c|c|c|}
\hline \multirow[t]{2}{*}{ Optimization of Taguchi } & \multicolumn{2}{|c|}{ Optimal cutting parameters } \\
\hline & Prediction & Experimental \\
\hline Ley & $\mathrm{A} 1 \mathrm{~B} 1 \mathrm{C} 3$ & A1B1C3 \\
\hline Parameters & $0.10 \quad 80 \quad$ КT315 & $0.10 \quad 80 \quad$ KT315 \\
\hline Average surface roughness & 11.7149 & 0.725 \\
\hline $\mathrm{S} / \mathrm{N}$ ratio & -233.656 & -2.7932 \\
\hline
\end{tabular}

Determining the minimum mean surface roughness values of the parameters for each level of the large $\mathrm{S} / \mathrm{N}$ ratio determined and created new verification experiment was conducted according to the test combination. ANOVA results for the main cutting force $\left(F_{\mathrm{z}}\right)$, surface roughness and $\mathrm{S} / \mathrm{N}$ ratio in Inconel 625 and Hastelloy $\mathrm{X}$ are provided in Tables 6-9. 
Table 12. Average surface roughness and verification test for the optimum results in Hastelloy X.

\begin{tabular}{|c|c|c|c|c|}
\hline \multirow[t]{2}{*}{ Optimization of Taguchi } & \multicolumn{4}{|c|}{ Optimal cutting parameters } \\
\hline & & Prediction & & xperimental \\
\hline Leve & \multicolumn{2}{|r|}{$\mathrm{A} 1 \mathrm{~B} 2 \mathrm{C} 3$} & \multicolumn{2}{|r|}{$\mathrm{A} 1 \mathrm{~B} 2 \mathrm{C} 3$} \\
\hline Paramete & 0.10 & 80 КC9240 & 0.10 & $80 \mathrm{KC} 9240$ \\
\hline Average surface $r$ & & 1.049 & & -2.72 \\
\hline $\mathrm{S} / \mathrm{N}$ ratio & & -0.4155 & & -56.82 \\
\hline
\end{tabular}

Table 13. Cutting force $\left(F_{\mathrm{z}}\right) \mathrm{SN}$ rates and verification test for the optimum results in Hastelloy $\mathrm{X}$.

\begin{tabular}{|c|c|c|c|c|}
\hline \multirow[t]{2}{*}{ Optimization of Taguchi } & \multicolumn{4}{|c|}{ Optimal cutting parameters } \\
\hline & & Prediction & & xperimental \\
\hline Level & & $\mathrm{A} 1 \mathrm{~B} 3 \mathrm{C} 3$ & & $\mathrm{~A} 1 \mathrm{~B} 3 \mathrm{C} 3$ \\
\hline Parameters & 0.10 & $100 \mathrm{KC} 9240$ & 0.10 & $100 \mathrm{KC} 9240$ \\
\hline Cutting force $\left(F_{\mathrm{z}}\right)$ & & 579.49 & & 538 \\
\hline $\mathrm{S} / \mathrm{N}$ ratio & & -55.2617 & & -54.61 \\
\hline
\end{tabular}

Results of confirmation tests for Cutting force (N) and surface roughness in Inconel 625 and Hastelloy X are provided in Tables $10-13$.

\section{Results and conclusions}

The experimental design described herein was used to develop a main cutting force and surface roughness prediction model roughness using analysis of Taguchi for turning Inconel 625 and Hastelloy X. Results of this experimental study can be summarized as follows:

- It has seen that while feed rate $(39.8 \%)$ and cutting tool (11.8\%) has higher effect on cutting force in Inconel 625 , the feed rate $(65.99 \%)$ and cutting speed $(11.14 \%)$ has higher effect on cutting force in Hastelloy X. While cutting tool $(23.7 \%)$ and feed rate $(16.5 \%)$ has higher effect on average surface roughness in Inconel 625, cutting tool $(40.38 \%)$, and feed rate $(33.15 \%)$ has higher effect on average surface roughness in Hastelloy X.

- According to obtained experiments data, the lowest main cutting force has found in Hastelloy X with KC 9240 insert as $538 \mathrm{~N}$ and in Inconel 625 as $483 \mathrm{~N}$ both at $100 \mathrm{~m} / \mathrm{min}$. In the same KC 9240 insert, lowest average surface roughness has found at $100 \mathrm{~m} / \mathrm{min}$ in Hastelloy X as $0.755 \mu \mathrm{m}$. And as $0.725 \mu \mathrm{m}$ at $65 \mathrm{~m} / \mathrm{min}$. in Inconel 625. It was seen the effect of cutting tool on surface roughness has found higher on Hastelloy X and Inconel 625.

- Taguchi orthogonal array arrangement, it has seen appropriate to analyzed the cutting force and average surface roughness defined in this article.

Acknowledgements. The authors would like to express their gratitude to University of Yuzuncu Y1l for the financial support Under Project No. BAP 2012-BYO-013.

\section{References}

1. Ezugwu EO, Wanga ZM, Machadop AR. 1998. The machinability of nickel-based alloys: a review. J. Mater Process. Technol., 86(1-3), 1-16.

2. Zhang Q, Tang R, Yin K, Luo X, Zhang L. 2009. Corrosion behavior of Hastelloy C- 276 in supercritical water. Corros. Sci., 51, 2092-2097.

3. Bohm H, Ehrlich K, Kramer KH. 1970. Metall., 24, 139-144.

4. Kohl HK, Peng K. 1981. J. Nucl. Mater., 101, 243-250.

5. Quist WE, Taggart R, Polonis DG. 1971. Metall. Trans., 2, 825-832.

6. Sundararaman M, Mukhopadhyay P, Banerjee S. 1988. Metall. Trans. A, 19, 453-465.

7. Charles T. 1994. Int. J. Press. Vessels Piping, 59, 41-49.

8. Shankar V, Rao KBS, Mannan SL. 2001. J. Nucl. Mater., 288, 222-232.

9. Shoemaker LE. 2005. Superalloys 718, 625, 706 and Various Derivatives. Loria EA, Editor. TMS: Warrendale, PA. p. 409-418.

10. Singh VB, Gupta A. 2000. The electrochemical corrosion and passivation behavior of Monel 400 in concentrated acids and their mixtures. Trans. JWRI, 34, 19-23.

11. Haynes Hastelloy C-22HS Standard Product Catalogue. 2007. Haynes International: Indiana. p. 2-16.

12. Jindal PC, Santhanam AT, Schleinkofer U, Shuster AF. 1999. Performance of PVD TiN, TiCN, and TiAlN coated cemented carbide tools in turning. Int. J. Recfrac. Met. Hard Mater., 17, 163-170.

13. Website of trademark owner of Hastelloy C-276. www.hynesintl.com.

14. Wang M. 1997. Ph.D. Thesis, South Bank University, London.

15. Richards N, Aspinwall DD. 1989. Use of ceramic tools for machining nickel-based alloys. Int. J. Mach. Tools Manuf., 29(4), 575-588.

16. Ezugwu EO, Wang ZM. 1996 Performance of PVD and CVD coated tools when machining nickel-based, Inconel 718 alloy, in Progress of Cutting and Grinding, Vol. 111. p. 102-107.

17. Khamsehzadeh H. 1991. Behavior of ceramic cutting tools when machining superalloys. $\mathrm{PhD}$ Thesis, Universtiy of Warwick.

18. Barry J, Byrne G. 2001. Cutting tool wear in the machining of hardened steels. Part I. Cubic boron nitride cutting tool wear. Wear, 247, 139-151.

19. Kramer BM, Hartung PD. 1980. Proc. Int. Conf. of Cutting Tool Mat.. Fort Mitchell, KY. p. 57-74.

20. Focke AE, Westermann FE, Ermi A, Yavelak J, Hoch M. 1975. Failure mechanisms Of superhard materials when cutting superalloys. Proc. 4th Int.-Am. Conf. Mat. Tech., Caracus, Venezuela. p. 488-497

21. Konig W, Berktold A, Liermann J, Winands N. 1994. Top quality components not only by grinding. Ind. Diamond Rev., 3 , 127-132.

22. Çakır C. 2000. Modern metal cutting principles. Vipaş: Bursa.

23. Valencia JJ, Spirko J, Schmees R. 1997. Superalloys 718, 625, 706 and Various Derivates. Loria EA, Editor. TMS: Warrendale, PA. p. 753-762.

24. Sun S, Brandt M, Dargusch MS. 2009. Characteristics of cutting forces and chi formation in machining of titanium alloys. Int. J. Mach. Tools Manuf., 49, 561-568. 
25. Ranganath S, Campbell AB, Gorkiewicz DW. 2007. A model to calibrate and predict forces in machining with honed cutting tools or inserts. Int. J. Mach. Tools Manuf., 47, 820-840.

26. Topal ES, Cogun C. 2005. A cutting force induced error elimination method for turning operations. J. Mater. Process. Technol., 170, 192-203.

27. Montgomery DC. 1997. Design and analysis of experiments, 4th edn. Wiley: New York.

28. Yavaşkan M, Taptık Y, ve Urgen M. 2004. Deney tasarımı yontemi ile matkap uclarında performans optimizasyonu. İTÜ Dergisi/d, 3(6), 117-128.

29. Nalbant M, Gokkaya H, Sur G. 2007. Application of Taguchi method in the optimization of cutting parameters for surface roughness in turning. Mater. Des., 28, 1379-1385.
30. Yang WH, Tarng YS. 1998. Design optimization of cutting parameters for turning operations based on the Taguchi method. J. Mater. Process. Technol., 84(1-3), 122-129.

31. Roy RK. 1990. A primer on the Taguchi method. Van Nostrand Reinhold: New York.

32. Tosun G. 2011. Statistical analysis of process parameters in drilling of AL/SIC $P$ metal matrix composite. Int. J. Adv. Manuf. Technol., 55(5-8), 477-485.

33. Taskesen A, Kutukde K. 2013. Optimization of the drilling parameters for the cutting forces in B4C-reinforced Al-7XXXseries alloys based onthe Taguchi method. Mater. Tehnol., 47(2), 169-176.

Cite this article as: Altin A: A comparative study on optimization of machining parameters by turning aerospace materials according to Taguchi method. Int. J. Simul. Multisci. Des. Optim., 2017, 8, A1. 